\title{
11 Bisexuality as an identity and a conceptual tool in sexual politics in Finland
}

\author{
Jenny Kangasvuo
}

\section{Introduction}

Bisexuality as a recognised identity started to emerge in the Finnish mainstream media in the early 1990s. Before that, bisexuality was a concept used in sexual minority politics as well as in porn and sensation magazines. However, a separate bisexual identity was not recognisable due to the generalised use of the concept. Only in the late 1980s did people who defined themselves as bisexual begin to be active in sexual minority politics. Currently, bisexuality is a visible part of sexual minority politics in Finland; however, the stereotypes drawn decades before continue to impact the experiences and identities of the people who define themselves bisexual.

The research on which this chapter is based has a time range of almost 50 years (Kangasvuo, 2014). Over those years, Finland experienced significant cultural changes that impacted the positions of bisexuality in the country's sexual culture. These positions have multiplied and transformed through the years. Today, bisexuality has several different and contrasting positions in the Finnish sexual culture. The motivation for the research lies in my own bisexual identification.

In this chapter, I answer the following questions: How was the concept of bisexuality formed in different decades in Finnish sexual culture? How has the bisexual identity become possible? What kinds of experiences do bisexual people have?

\section{Research material and methods}

The research material consists of interview data, data gathered via participant observation, and media texts. I attended numerous bisexual groups, parties, and conventions during the research process from 1999 to 2014.

I used ethnographical writing to analyse the research material (see Richardson \& St Pierre, 2005). My theoretical background is based on the ideas of symbolic anthropology that rely on ethnographical thick description as described by cultural anthropologist Clifford Geertz (1993). 


\section{Jenny Kangasvuo}

I contextualised my findings by taking the time period and cultural situation into account when analysing the data.

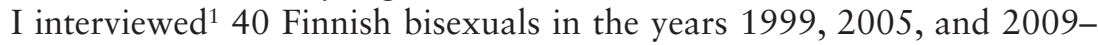
2010. All together 52 interviews were conducted and 12 interviewees were interviewed twice. The interviews form a longitudinal study on the experiences and identities of Finnish bisexuals.

I collected material from three different fields of the media from the time period 1969-2011. First, I analysed publications ${ }^{2}$ by Finnish organisations that concentrate on sexual minority politics. Second, I analysed volumes of Finnish porn magazines from four decades. Third, I collected bisexualitythemed articles from mainstream magazines and newspapers. I used critical discourse analysis (Fairclough \& Wodak, 1997) to examine the media texts.

The complexity and the long timeline of the research material mean it is possible to make informed generalisations about the status and the role of the concept of bisexuality in Finnish sexual culture. In this chapter, I refer to my research material in the following manner: if I highlight the research material specifically - for instance, "porn magazines of 1990s" - the argument is based on this material. When I do not refer to specific research material, my argument is a generalisation drawn from all the material. Certain themes and forms constantly repeat in discussions that concern bisexuality. I aim to frame the discussions and themes within a more general cultural context.

\section{Changes in legislation}

Legislation provides a timeline for understanding the changes in sexual culture. In Finland, "same-sex fornication" (RL 20:12\$) was decriminalized in 1971. Finland decriminalised homosexual acts quite late compared with other Nordic countries. For example, same-sex sexuality was permitted in Denmark in 1933, in Iceland in 1940, and in Sweden in 1944. Norway decriminalised same-sex sexuality as late as in 1972 (Rydström, 2007). Legislative and cultural changes in Sweden were observed closely in Finland through the post-war decades and also used as examples for Finnish legislation.

Before 1971, Finnish discussions about same-sex sexuality were centred around its criminality, as well as homosexuality as a psychiatric diagnosis for sexual deviation. Public discussions about same-sex sexuality as lived experiences or as an identity became fully possible only after the decriminalisation. However, concurrently with the decriminalisation, a new law was written: "public encouraging to fornication with a person of the same sex" (RL 20:9\$) became prohibited by law. The punishment ranged from monetary fines to up to six months in prison. The law was passed, although there was already a strict law on the distribution of obscene publications (Ri 5 28.1.1927/23), which made it possible to regulate public discussions about sexuality in general (Jyränki, 2007). 
The reasoning behind the new law was the psychiatric theory that homosexuality was a disease, and that any positive information about it would prevent people from getting treatment. Homosexuality was not a criminal act anymore, but it was still seen as a disease. It was assumed that public discussions about homosexuality would make it spread wildly among the general public. The law prohibiting encouraging homosexuality led to charges only twice during the 28 years that it was in effect, and no sentences were handed down. In 1981, the National Board of Health removed samesex sexuality from the list of psychosexual disorders, but the law remained. The law was abolished only in 1999, but it was not truly enforced after the early 1980s (Stålström, 1997; Stålström \& Nissinen, 2003).

However, the law induced self-censorship among the mainstream media, especially in the Yleisradio, the publicly funded national broadcasting company (Månsson, 1984). The law resulted in same-sex sexualities being ignored by the Finnish media. As homosexuality was silenced in the mainstream media, so was bisexuality. In the 1970s and early 1980s, same-sex sexualities were only written about in media that were not perceived as respectable or mainstream. Same-sex sexualities - as well as non-normative genders - were discussed in porn magazines, sensational magazines, and sexual minority political publications (Juvonen, 2004). Thus, these "nonrespectable, non-mainstream" publications form the core of my research material.

While porn magazines did use pornified stereotypes of bisexuality and other sexualities in porn stories and other material that aimed to excite the reader, they also published articles that aimed to educate and inform their audience. It is noteworthy that porn magazines attended public and political discussions about sexuality, and during the decades of self-censorship of the mainstream media, porn magazines covered issues of sexual and gender minorities in a positive and accepting manner. Porn magazines took a diverse approach to sexuality in general (Paasonen, 2009).

The sexual minority rights remained somewhat unchanged until the 2000s, but discrimination based on sexual orientation at work and in services became prohibited in 1999. The act on registered partnership for samesex couples was passed in 2001 (L 9.11.2001/950) and, with the exception of adoption rights and the right to take the same family name, the law was comparable to the marriage law. Adoption within the family - that is, adopting the child of the registered spouse - became possible in 2009, but adoption outside the family was still prohibited (L 8.2.1985/153). Another law that regulates family rights of same-sex couples is the law on infertility treatment that was passed in 2006 (L 22.12.2006/1237). The law makes artificial insemination judicially available for female couples. Before this, individual clinics decided themselves whether or not to give treatment to female couples.

In early years of the 2010s, the discussions about marriage rights became more heated. In 2013, Citizens' Initiative for Equal Marriage Law gained 
the needed 50,000 signatures in less than a day (Lahti, 2015). The law was passed in 2014 and became effective in 2017. It removed the mention of the partners' sex from the marriage law. Since then, there has been no difference in marriage rights of same-sex or different-sex couples (Avioliittolaki 1929, p. 234).

\section{Universal bisexual desire legitimises homosexuality}

Bisexuality as an identity - or indeed any sexual identity - is possible only in a cultural atmosphere where sexual desire is assumed to be essential for the understanding of oneself. A cultural atmosphere like this is not a given: even if same-sex desires and sexual acts have been present in all human cultures and communities, it is only in some of them that the sexual desire and sexual acts are assumed to define a person's identity in an essentialist way.

Analysis of publications of sexual minority political organisations shows that in early Finnish sexual minority politics, the role of bisexuality was to legitimate homosexuality. Human sexuality was defined as universally bisexual and all people were seen to have at least some bisexuality in them. The universal nature of bisexuality was used to make same-sex desire and homosexuality more understandable and acceptable within the culture. Thus, it was claimed that condemning homosexuality would mean condemning humanity in and of itself, since humanity was seen to be essentially bisexual.

The idea of a universal bisexual desire as universal possibly has its origins in simplifications of Alfred Kinsey's studies of human sexuality, and the lay interpretations of Sigmund Freud's psychoanalytical theory. Interestingly, these two authorities of bisexuality are mentioned in all my material porn magazines, publications of sexual minority organisations, and the interviews - and in all decades of this study.

Sexual minority political organisations' publications portrayed people who defined themselves as homosexual as conscious of their bisexual nature, which connected all people. In the 1970s, homosexuality did not mean exclusive same-sex desire, but same-sex desire in general. A homosexual was a person who chose to be honest about his (sic) sexual desire and who rejected normative life choices such as marriage.

Bisexuals were presented as people who were not ready to name themselves as homosexual, despite their same-sex desire. Bisexuality meant a fearful retreat to normative life choices and declining a homosexual identity. These "bisexual men" were described either as dishonest or as victims of the sexually repressed culture. Also in porn magazines, bisexuality was provided to the reader as a term that could be used if one could not or did not dare to name himself (sic) as homosexual. Bisexuality was presented as a safer and less radical way to define oneself than homosexuality. "Bisexuality" was not a term used by the men themselves, but rather one with which they were defined from the outside. There was no room for an open and public bisexual identity. 
In porn magazines, this use of the concept of bisexuality prevailed from the 1970s to the 2000s. However, bisexuality as a mild version of homosexuality vanished from the publications of sexual minority political associations before the early 1990s, about the same time bisexuality became recognised as a sexual identity distinct from homosexuality.

In the 1970s, bisexuality was seen either as the potential of sexuality that united humanity, or an unidentified potential of homosexuality in a person. Bisexuality was considered a form of homosexuality, something that was a result of rejecting or being ashamed of same-sex desire, or being ignorant about the possibility of homosexual identity. Before the 1990s, bisexuality was a non-identity and it had no political content. The term acquired political meaning only when it was used in the discussions that concerned homosexuality and homosexual identity. Bertilsdotter Rosqvist (2012) has gained comparable results by analysing the discourses on marriage and married men in the Swedish gay press published in the period 1954-86.

Since the 1970s, bisexuality has been used to explain and legitimise same-sex desire. In a cultural situation in which same-sex desire was seen as threatening or repulsive, the concept of bisexuality made homosexuality more comprehensible. If bisexuality connects all people, it also shows how homosexuality and heterosexuality are parallel to each other.

\section{Bisexual identity becomes possible}

The first people who identified as bisexual started to be active in sexual minority organisations in the early years of the 1990s. These early activists wrote about bisexuality and talked openly about it. As a result of their identity political activism, bisexuality became a publicly acknowledged concept within sexual minority organisations as well as a sexual identity, and a basis for forming sexual communities and discussion groups. The change is manifested in the texts published in sexual minority associations' magazines that were written by self-identified bisexuals, but also in the texts published in mainstream magazines and newspapers, in which bisexuality was presented as "a new phenomenon". Bisexuality as a sexual minority political identity became visible also to the mainstream culture.

In 1997, Helsingin Sanomien Kunkausiliite, the monthly magazine of the most prominent newspaper of Finland, published a big article on bisexuality. The bisexuals interviewed for the article were presented with their own names and faces. The article marks the point after which it was culturally more acceptable to name oneself publicly as bisexual than before. Most of my interviewees remembered the article and said they were glad about the visibility that bisexuality gained through the article.

The talk about bisexual identity strived to break prejudices of bisexuality and diversify the notions of sexuality in general, as well as make bisexual people acceptable in gay and lesbian communities. Bertilsdotter (2001) has shown that the visibility of bisexuality increased in Swedish LGBT 
movement in the same decade: openly bisexual people became active in gay and lesbian organisations, the first discussion groups for bisexuals were organised, bisexuality was written about in magazines, a mailing list for bisexual activists was created, and the first bi section was organised in the Stockholm Pride parade in 1999. Finnish bisexual activists worked together with Swedish and international activists and attended events organised by bisexual activists around Europe.

During the same decade, the term "queer" emerged in Finnish sexual minority political discussions. The term was adopted as is; it was not translated into Finnish. Some suggestions for translation of the term "queer" appeared, but none of them took root in sexual political activism. The discussions of the concept of queer and the bisexual identity were concurrent. It is possible that the discussions about queer made the bisexual identity politically comprehensible, since queer shook the categories of homosexuality and heterosexuality, both of which are based on the idea of monosexuality (see Hemmings, 1997). My informants were very conscious about the discussions about queer already in 1999: most of them recognised the term and some had also read international queer activist texts.

The experiences of my interviewees demonstrate the increased availability of the concept of bisexuality as a tool for identification in the 1990s. The interviewees born before the 1970s said that they encountered the term "bisexuality" only in the 1990s, and formed their bisexual identity in adulthood, even in their late middle age. Before the 1990s, bisexuality as a concept was not used to define sexual identity widely enough for the concept to be accessible or understandable. The younger interviewees, by comparison, did not need to find the term "bisexual", since it was already culturally available. Identifying as bisexual was easier to them than it had been to earlier generations.

\section{The demarcation of the concept of homosexuality}

Over the 15 years during which I have studied bisexuality, there have been changes in the accessibility of a bisexual identity. For example, I interviewed women who had initially identified as lesbian, because the term was more accessible for self-definition when they recognised their potential for samesex desire (Kangasvuo, 2006). It was only later that they encountered the term "bisexual" and realised that bisexuality described their sexual desire and life experiences better than the term "lesbian". Initially the concept of bisexuality either was not familiar to them at all, or they had seen it to be used only in pornified and hypersexualised contexts to which they did not relate.

The term "lesbian" also offered a chance to join lesbian communities when bisexual communities did not yet exist. A lesbian identity was culturally comprehensible: it provided the possibility of following a clear identity-forming process that included coming out of the closet, being 
sexual politically active, and becoming a member of lesbian communities. It was only in the late 1990s that the concept of bisexuality became public and multifaceted enough that these women could relate to it (Kangasvuo, 2006).

However, some of these women chose to define themselves as both bisexual and lesbian. Often they were publicly lesbian and privately bisexual. Some said they were completely closeted bisexuals in lesbian communities, and expressed that their public identity was lesbian mainly due to the prejudices against bisexuality in lesbian communities (Ault, 1996; Bower et al., 2002; Maliepaard, 2017). For others, "being lesbian" did not refer to sexual desire but relationship choices and belonging to lesbian communities; they used the term "lesbian" since it was a more comprehensible term than "bisexual":

If someone thinks that it's just my sexual orientation that I refer to when I say I am lesbian, then they might also say that I am bluffing. If other people would be free from the stigma that is linked to the sexual preferences, then I could say publicly that I am bisexual.

(Female interviewee, born 1976, interviewed 2005)

The binegativity in lesbian and gay communities has been studied and shown to be prevalent in countries other than Finland - for instance, Sweden (Gustavson, 2006), the United Kingdom (Barker et al., 2012), France (Welzer-Lang, 2008), the United States (Mulick \& Wright Jr, 2002), and Australia (McLean, 2008).

The option of a bisexual identity in the current sexual culture also means that gay and lesbian identities have become narrower. While in the 1970 s and the 1980s homosexuality meant that same-sex desire was present in a person's repertoire of desire, in the 1990s homosexuality started to mean that different-sex desire was excluded from a person who felt same-sex desire. In the 1970s, same-sex desire was not contrasted with differentsex desire - namely heterosexuality - but with normative life choices like marriage. Same-sex desire and normative life choices were presented as mostly incompatible, except in very special circumstances. "Gay man and his wife", as described in a title of an article published in a porn magazine in 1977, could live happily together if the wife (assumed to be heterosexual) understood the same-sex desire of her husband.

In the current sexual culture, homosexuality is monolithic and does not have space for different-sex desire. According to my interviewees, differentsex desire is often seen as improper in lesbian and gay communities, as well as in those cases in which a member of these communities defines their sexuality as bisexual. The interviewees told how their bisexuality was repeatedly questioned in gay and lesbian communities, and said this othering contributed to separate homosexual and bisexual identities. "How can you define yourself as bisexual? Don't you think about your girlfriend's feelings at all?" one female interviewee (born 1975, interviewed 2009) was asked 
by a member of a lesbian community to which she belonged. Bisexual selfdefinition made the interviewee's attachment to her partner questionable in the opinion of the members of the lesbian community. Lahti $(2015,2018)$ has studied Finnish bisexual women's relationships and shown that bisexuality does not fit into the normative discourse about relationships. Thus, it tends to become invisible regardless of the gender of the partner. Reflecting the experience of my interviewee, bisexuality is also forced to become invisible in lesbian communities due to the prejudices against it.

Thus, the concept of bisexuality has also formed the concept of homosexuality. The possibility of different-sex desire is completely excluded from the concept of homosexuality. My Finnish research results can be compared with the interpretation of Angelides (2001), according to whom the concept of homosexuality has become more rigid since the emergence of the concept of bisexuality in the field of sexual politics. Homosexuality has grown to become the most recognisable sexual identity that is juxtaposed with the self-evident normativity of heterosexuality. Compared with them, bisexuality is still seen as a fleeting phenomenon.

\section{The hypersexualised bisexuality}

By the 2000s, bisexuality had become a concept that referred mostly to young women's sexuality and not to married men's sexuality, as it was in the 1970s and the early 1980s. Especially in the mainstream media, the word "bisexual" was linked to young women. In this use, the term appears as transitory and temporary, describing something that one will grow out of (see also Gomillion \& Giuliano, 2011; Kangasvuo, 2002). While the bisexuality of married men appeared as problematic, since it indicated a same-sex desire that could threaten marriage and a heteronormative lifestyle, it was still presented as intrinsic and immutable. In contrast, the bisexuality of young women appeared as exciting, ephemeral, and fashionable. This means that in the current Finnish sexual culture it is easier for young women to recognise and name their sexual desire as bisexual than it is for other age groups of women or men in general. In the Finnish sexual culture, there is space for young woman's bisexuality, but the space is very narrow, and it gets narrower when the woman ages.

From the 1990s to the 2010s, young women's bisexuality was used to titillate and excite the audiences of both porn magazines and the mainstream media, especially tabloid newspapers. Bisexuality provided a fantasy to be consumed by different audiences. Young women's bisexuality was described and represented in a voyeuristic way - indeed, the primary way to illustrate articles about bisexuality was to show young women with feminine appearances in erotic situations with each other. The mainstream media texts also approached bisexuality in a pornified manner (Kangasvuo, 2007).

Interestingly, in the porn magazines of the 2000s, bisexuality was addressed from several different perspectives when compared with the 
mainstream media texts. Porn magazines published more texts about bisexuality than the mainstream media, and while a single text published in a mainstream magazine aimed to explain "this new and unknown phenomenon" fully, the audiences of porn magazines could be assumed to be familiar with bisexuality to start with. Porn magazines can be seen as forums for sexual education and enlightenment about sexuality compared with the mainstream media, which that often used repeating discourses and stereotypes of bisexuality.

The number of texts that concerned bisexuality increased from the 1990s to the 2010s, and this increase indicates a certain tendency in the mainstream media in which bisexuality has gotten more space than in the earlier decades. Bisexuality in and of itself cannot be defined as a trend, but the ways in which it is treated in the Finnish media can be described as trendlike. Nevertheless, trendiness is an inseparable stereotype of bisexuality. Furthermore, the increased number of media texts that consider bisexuality and people who identify as bisexual reflects an increased interest in bisexuality. Bisexuality is not a neutral term when it is used in the media. The stereotypes and notions linked to bisexuality do not cease to charm Finnish media audiences - bisexuality can still titillate both the audiences of porn and those of mainstream media.

Yet even after bisexuality became a separate identity category in the 1990s, it appears to have been less essential and more oriented towards pleasure than gay and lesbian identities, not to mention normative heterosexual identities. This attitude can also be seen in discussions about nonmonogamous and bisexual people.

The discussions about non-monogamy became more difficult in the mid2000s within Finnish gay and lesbian communities when the idea of respectability of same-sex sexualities became a central theme in sexual minority politics. Monogamy and respectability were linked to each other (Jyränki et al., 2007; Kangasvuo, 2011; Kuosmanen, 2007a, 2007b; Lahti, 2015). The normative discourse excluded those bisexuals who lived in non-monogamous relationships, and sexual minority politics did not leave space for polyamory or non-monogamous relationships in the context of bisexuality, since they would have verified the stereotype of bisexuals as hypersexual. For bisexuality to become respectable, it also had to be monogamous.

The public discussions about polyamory and multiple relationships have resurfaced only in the late 2010s, and the media discussions about polyamory are often linked to the discussions about bisexuality. There have been several publicly open media personalities who have talked about their polyamory and bisexuality in the Finnish media. ${ }^{3}$ In public discussions of polyamory, it is described in the same kinds of identity political ways in which the essentiality of polyamory is emphasised. Polyamory is not presented as a relationship choice or a way of life, but as an identity. The meaning of pleasure is downplayed in the discussions that consider polyamory, and love, communication, and emotional attachment are emphasised. The media 


\section{Jenny Kangasuno}

discussions that consider polyamory and polyamorous identity politics are parallel to the media discussions and identity politics of bisexuality (see Matilainen, 2012), since in both discussions non-monogamies are repeatedly negotiated.

As such, bisexual identity is a more private and less visible identity than other sexual identities, and it becomes visible only when related to pleasure or non-monogamous relationship practices. Bisexuality as a concept is linked to other sexual categories that do not engage in identity political activism, namely kinky, fetish, and BDSM sexualities, which appear more as categories of pleasure and less as categories of identity (see also Juvonen, 2019). In particular, the interviewed couples who engaged in swinging used the term "bisexuality" to describe their sexual pleasure and sexual activities rather than their sexual identity.

Some interviewees commented that the stereotype of bisexuals as hypersexual might have its origins in the sex-negative attitudes of the culture. They said that as bisexuals they have learned to embrace and accept their sexuality, while the people who inhibit parts of their sexualities or who have a sex-negative attitude may perceive bisexuals as hypersexual. By saying this, the interviewees positioned themselves as sex-positive.

It seems that the interviewees' attitudes towards the stereotype of hypersexuality changed in the first decade of the 2000s. However, it is not possible to say whether the change is due to the ageing of the interviewees or a cultural change. The discussion between a female and a male interviewee, a couple I interviewed in 1999 and 2010, illustrates the change in attitudes towards the stereotype of hypersexuality:

MALE: Ten years ago everybody had a strong need to prove that bisexuals are ordinary people. We are not constantly horny and we don't need many relationships and we can be in one monogamous relationship.

FEMALE: I don't get it, why should we need to prove that we are like everybody else? What's the profit in being like everybody else? Isn't it better to be like you feel good to be?

MALE: Ten years ago there was this strong prejudice that bisexuals are whore ass sluts.

FEMALE: Maybe. And it was like being a whore ass slut would be a bad thing.

MALE: Yeah. I used the words whore ass slut as a positive term.

FEMALE: You owned it.

MALE: I'm an empowered whore ass slut. [laughs]

(Female interviewee, born 1970 and male interviewee, born 1974, interviewed 2010)

Of course, the mainstream heteronormative culture is not monolithic in its attitude towards sexuality and sexual minorities. Therefore, the interviewees' explanation of bisexuality as a sex-positive attitude does 
not reflect mainstream culture in and of itself, but rather shows how the interviewees define bisexuality as liberal, modern, and tolerant in contrast to the heteronormative mainstream culture, which they define as traditional, conservative, and intolerant. However, it must be noted that according to the Eurobarometer (2019), the Finnish attitudes towards sexual minorities are generally more tolerant than those in other European Union countries.

Hypersexuality is linked to other non-heterosexualities as well, and especially to gay men (Mowlabocus, 2007). However, in the Finnish mainstream media, the stereotypes of lesbians and gay men have gradually shifted from pornified arenas to the arenas of respectability and ordinariness after the legislative changes and the public discussions about sexual minority rights. This change has taken place since the 2000s. In contrast, the stereotypes of bisexuality do not have any hint of ordinariness or respectability: bisexuality has remained a culturally acceptable object of pornification in the Finnish media landscape (Kangasvuo, 2007).

Even today, in the Finnish mainstream media, bisexuality is presented as a less essential and more hedonistic identity than gay and lesbian identities not to mention the normative heterosexual identity. Bisexuality is useful for entertaining and titillating different audiences, both in porn and mainstream media, but it has remained an identity that is not fully acknowledged in the Finnish sexual culture.

\section{Conclusion}

In this chapter, I traced the position of bisexuality in the Finnish sexual culture, which reflects the changes in culture and sexual politics, particularly the increased acceptability and conceivability of sexual and gender minorities in Finland in general.

One of the most significant changes in the use of the concept of bisexuality in the Finnish sexual culture relates to who it refers to. In the first decades of the studied time period, in the 1970s and 1980s, bisexuality was a concept used to describe either universal human sexuality, or men who suppressed their same-sex desire while enjoying the privilege of a heteronormative lifestyle. From the late 1980s onwards, bisexual identity politics emerged in the sexual minority political organisations and in the 1990s bisexuality became a valid sexual identity option. In the decades that have followed, the concept of bisexuality has mostly been used to describe young women's sexuality in the media. The concept of bisexuality has been clearly gendered during the researched period, but the mid-1990s marked a shift in the gendering of the concept.

However, one must remember that the youngest interviewee of the research was born in 1981. This research does not discuss how the younger generations in Finland define themselves and what bisexuality means to them. It seems that people born in the late 1980s, 1990s and the early years of the 2000s may define themselves with other terms than "bisexual". 


\section{Jenny Kangasvuo}

Anecdotal evidence indicates that among the younger generations, "pansexuality" seems to be a more popular term than "bisexuality" to define sexual desire and sexual experiences that do not fit into the conceptual boxes of heterosexuality or homosexuality.

In her recent article, Juvonen (2019) traces the terms used in self-naming. According to her study, the binary categories of gender and sexuality are in flux in Finland, especially among the younger generations. The variety of terms used for identification has increased: in addition to pansexuality, other seminal terms have emerged, such as "demisexuality" and "asexuality", which do not exclude other identity terms. For the informants of Juvonen's study, the boundary between bisexuality and pansexuality was random and fluid. The use of the terms depended on the context in which people talked about their identity and desire. The definitions of bisexuality and pansexuality overlap. Studies conducted in other countries have also shown that people may refer to their sexual identity as queer, pansexual and bisexual at the same time. Identities are seen as transcendent and as entailing potential to change (Flanders et al., 2017; Galupo et al., 2017).

The emergence of bisexuality as a sexual identity resulted in a more precise demarcation of homosexuality, as I have shown in this chapter. The concept of pansexuality may have similar effects on the concept of bisexuality in the future, but the concepts may also conflate into each other. Either way, for my interviewees, bisexuality is still a meaningful term to describe their identities and life experiences, and in the past three decades it has also gained comprehensibility in Finnish sexual culture. Bisexuality no longer needs to be constantly explained.

\section{Notes}

1 The birth years of the interviewees range from 1955 to 1981 . Some 25 per cent of the interviewees were men. The gender discrepancy of the research material is partly due to the fact that Finnish bisexual activists tend to be women, which makes them eager to take part in a study like this. The discrepancy partly reflects the difference between genders (Kontula, 2008). Finnish culture grants women more fluidity in presenting their sexual desire than it does men. None of the interviewees defined themselves as transgender or other-gendered.

2 Publications were magazines, radio programs and information booklets. In Finland, the most prominent national organisation Seta - Seksuaalinen Tasaveroisuus ry. (Sexual Equality) has been a common arena for men, women and other-gendered people. There have been some associations that were aimed at only men or women, but they are or were small. Seta has been the main route to advance sexual minority politics. Seta has had, and still has, local sub-organisations around the country.

3 For example, the young adult writer Siiri Enoranta and the stand-up comedian Juuso Kekkonen. Kekkonen's hugely successful work Outo homo (Strange Gay, 2012) centred on his polyamory and his experiences during the trans-process of his spouse. 


\section{References}

Angelides, S. (2001). A History of bisexuality. Chicago, IL: University of Chicago Press.

Ault, A. (1996). Hegemonic discourse in an oppositional community: Lesbian feminist stigmatization of bisexual women. In B. Beemyn, \& M. Eliason (Eds.), Queer studies: A lesbian, gay, bisexual, and transgender anthology (pp. 204-16). New York: New York University Press.

Barker, M., Richards, C., Jones, R., Bowes-Catton, H., Plowman, T., Yockney, J., \& Morgan, M. (2012). The bisexuality report: Bisexual inclusion in LGBT equality and diversity. Maidenhead: Centre for Citizenship, Identities and Governance and Faculty of Health and Social Care, The Open University.

Bertilsdotter, H. (2001). Maskrosbarn: Den internationella och svenska birörelsens historia [Dandelion child. The history of international and Swedish bi movement]. Lambda Nordica, 7(1-2), 84-91.

Bertilsdotter Rosqvist, H. (2012). A special kind of married man: Notions of marriage and married men in the Swedish gay press, 1954-1986. Journal of Historical Sociology, 25(1), 106-25. doi: 10.1111/j.1467-6443.2011.01410.x

Bower, J., Gurevich, M. \& Mathieson, C. (2002). (Con)tested identities: Bisexual women reorient sexuality. Journal of Bisexuality, 2(2-3), 23-52.

Eurobarometer (2019). Eurobarometer on discrimination 2019: The social acceptance of LGBTI people in the EU. Geneva: European Commission.

Fairclough, N., \& Wodak, R. (1997). Critical discourse analysis. In T.A. van Dijk (Ed.), Discourse as social interaction: Discourse studies 2 - a multidisciplinary introduction (pp. 258-84). Thousand Oaks, CA: Sage.

Flanders C.E., Lebreton, M.E., Robinson, M., Bian, J., \& Caravaca-Morera J.A. (2017). Defining bisexuality: Young bisexual and pansexual people's voices. Journal of Bisexuality, 17(1), 39-57. doi: 10.1080/15299716.2016.1227016

Galupo, M.P., Ramirez, J.L., \& Pulice-Farrow, L. (2017). "Regardless of their gender": Descriptions of sexual identity among bisexual, pansexual, and queer identified individuals. Journal of Bisexuality 17(1), 108-24. doi: 10.1080/ 15299716.2016.1228491

Geertz, C. (1993 [1973]). The interpretation of cultures. London: Fontana.

Gomillion, S.C. \& Giuliano, T.A. (2011). The influence of media role models on gay, lesbian, and bisexual identity. Journal of Homosexuality, 58(3), 330-54. doi: 10.1080/00918369.2011.546729

Gustavson, M. (2006). Blandade känslor. Bisexuella kvinnors praktik \& politik [Mixed feelings. The practice and politics of bisexual women]. Göteborg: Kabusa Böcker.

Hemmings, C. (1997). Bisexual theoretical perspectives: Emergent and contingent relationships. In $\mathrm{Bi}$ Academic Intervention (Ed.), The bisexual imaginary: Representation, identity and desire. London: Cassell.

Juvonen, T. (2004). Nyt se näkyy, nyt taas ei. Heteronormatiivisuus ja homo seksuaalisuuden esillepano Helsingin Sanomissa [Now you see it, now you don't: Heteronormativity and representations of homosexuality in Helsingin Sanomat]. Tiedotustutkimus, 27(1), 34-55.

Juvonen, T. (2019). Nimeämisen mahti. Sukupuolta ja seksuaalisuutta kuvaavien termien suhteisuudesta [The power of naming. The relatedness of the terms that 
describe gender and sexuality]. SQS - The Journal for Queer Studies in Finland, 13(1-2), 1-22. doi: https://doi.org/10.23980/sqs.89126

Jyränki, J. (2007). Pahennus, julkinen tila ja siveellinen tapa - epäsiveellisten julkaisujen sääntely- ja käsitehistoriaa Suomessa [Contempt, public space and decency - the Finnish history of regulation and concepts of indecent publications]. Oikeus, 36(1), 75-100.

Jyränki, J., Kangasvuo, J., Jokila, H., \& Sorainen, A. (2007). Intiimiyden uudet normit: Monisuhteisuus haastaa uuskunniallisuuden? [The new norms of intimacy: Is nonmonogamy challenging neo-respectability?] SQS - The Journal for Queer Studies in Finland, 2(1), 62-77.

Kangasvuo, J. (2002). Bisexuality as a concept in Finland: Signs of cultural change? Lambda Nordica, 8(3-4), 150-58.

Kangasvuo, J. (2006). Joustolesbot identeettihississä [Flexilesbians in the elevator of identity]. In T. Kinnunen \& A. Puuronen (Eds.), Seksuaalinen ruumis. Kulttuuritieteelliset lähestymistavat (pp.198-214). Helsinki: Gaudeamus.

Kangasvuo, J. (2007). Insatiable sluts and almost gay guys: Bisexuality in porn magazines. In S. Paasonen, K. Nikunen, \& L. Saarenmaa (Eds.), Pornification: Sex and sexuality in media culture (pp. 139-50). New York: Berg.

Kangasvuo, J. (2011). “There has been no phase in my life when I wasn't somehow bisexual": Comparing the experiences of Finnish bisexuals in 1999 and 2010. Journal of Bisexuality, 11(2-3), 271-89. doi: 10.1080/15299716.2011.571989

Kangasvuo, J. (2014). Suomalainen biseksuaalisuus. Käsitteen ja kokemuksen kulttuuriset ehdot [Finnish bisexuality: The cultural terms of the concept and experience]. Acta B 121 Humaniora. Oulu: University of Oulu.

Kekkonen, J. (2012). Outo homo [Strange Gay]. Stand up comedy show.

Kontula, O. (2008). Halu \& intohimo. Tietoa suomalaisesta seksistä [Desire \& passion. Information about Finnish sex]. Helsinki: Otava.

Kuosmanen, P. (2007a). Johdanto: Sateenkaariperheet, julkiset tilat ja queerpolitiikka Suomessa [Introduction: Rainbow families, public spaces and queer politics in Finland]. SQS - The Journal for Queer Studies in Finland, 2(1), 1-21.

Kuosmanen, P. (2007b). Sateenkaarifamilistinen käänne ja suomalaisten sateenkaarivanhempien muuttuvat perhemuodot [Rainbow familistic turn and the changing family forms of Finnish rainbow parents]. In P. Kuosmanen, \& J. Jämsä (Eds.), Suomalaiset sateenkaariperheet sosiaali- ja terveyspalveluissa ja koulussa [Finnish rainbow families in social and health services and at school]. (pp. 37-44). Helsinki: Edita.

Lahti, A. (2015). Similar and equal relationships? Negotiating bisexuality in an enduring relationship. Feminism \& Psychology, 25(4) 431-48. doi: 10.1177/ 0959353515574786

Lahti, A. (2018). Bisexual desires for more than one gender as a challenge to normative relationship ideals. Psychology \& Sexuality 9(2), 132-47. doi: 10.1080/ 19419899.2018.1441896

Maliepaard, E. (2017). Bisexuality in the Netherlands: Connecting bisexual passing, communities, and identities. Journal of Bisexuality, 17(3), 325-34. doi: 10.1080/ 15299716.2017.1342214

Matilainen, J. (2012). Polyamory and kinship in Finland. Negotiating love, equality and the self. Master's thesis, University of Helsinki. 
McLean, K. (2008). Inside, outside, nowhere: Bisexual men and women in the gay and lesbian community. Journal of Bisexuality, 8(1-2), 63-80. doi: 10.1080/ 15299710802143174

Mowlabocus, S. (2007). Gay men and the pornification of everyday life. In S. Paasonen, K. Nikunen, \& L. Saarenmaa (Eds.), Pornification: Sex and sexuality in media culture (pp. 61-71). New York: Berg.

Mulick, P.S., \& Wright, L.W. Jr (2002). Examining the existence of biphobia in the heterosexual and homosexual populations. Journal of Bisexuality, 2(4), 45-64. doi: 10.1300/J159v02n04_03

Månsson, U. (1984). Synti, rikos, ihmisoikeus - oikeustaistelun historiaa ja nykypäivää [Sin, crime, human right - history and present of the fight for justice]. In K. Sievers \& O. Stålström. (Eds.), Rakkauden monet kasvot. Homoseksuaalisesta rakkaudesta, ihmisoikenksista ja vapautumisesta. Helsinki, FI: Weilin+Göös.

Paasonen, S. (2009). Healthy sex and pop porn: Pornography, feminism and the Finnish context. Sexualities 12(5), 586-604. doi: 10.1177/1363460709340369

Richardson, L., \& St Pierre, E.A. (2005). Writing: A method of inquiry. In N.K. Denzin \& Y.S. Lincoln (Eds.), The Sage handbook of qualitative research (pp. 959-78). Thousand Oaks, CA: Sage.

Rydström, J. (2007). Introduction: Same-sex sexuality and the law in Scandinavia 1842-1999. In J. Rydström \& K. Mustola (Eds.), Criminally queer. Homosexuality and criminal law in Scandinavia 1842-1999 (pp. 13-40). Amsterdam: Aksant.

Stålström, O. (1997). Homoseksuaalisuuden sairausleiman loppu [The end of the medicalisation of homosexuality]. Tampere, FI: Gaudeamus.

Stålström, O., and Nissinen, J. (2003). Homosexuality in Finland: The decline of psychoanalysis' illness model of homosexuality. Journal of Gay \& Lesbian Psychotherapy, 7(1/2), 75-91. doi: 10.1300/J236v07n01_06

Welzer-Lang, D. (2008). Speaking out loud about bisexuality: Biphobia in the gay and lesbian community. Journal of Bisexuality, 8(1-2), 81-95. doi: 10.1080/ 15299710802142259

\section{Laws}

Avioliittolaki 13.6.1929/234. [Marriage Act.]

Laki hedelmöityshoidoista 22.12.2006/1237. [Act on Infertility Treatment.]

Laki lapseksi ottamisesta 8.2.1985/153. [Act on Adoption within the Family.]

Laki rekisteröidystä parisuhteesta 9.11.2001/950. [Act on Registered Partnerships.]

Ri 5 Laki epäsiveellisten julkaisujen levittämisen ehkäisemisestä 28.1.1927/23. [Act on Prevention of Distribution of Indecent Publications.]

RL 20:5 . Rikoslaki 19.12.1889/39. Luku 20 (15.1.1971/16.) Siveellisyysrikoksista. $5 \$$ Nuoreen henkilöön kohdistuvasta haureudesta. [Criminal Act. On Indecencies. 5 \ On Fornication with a Young Person.]

RL 20:9 S. Rikoslaki 19.12.1889. Luku 20 (15.1.1971/16.) Siveellisyysrikoksista. 9 S Kehottamisesta samaa sukupuolta olevien haureuteen. [Criminal Act. On Encouraging to Fornication with a person of the Same Sex.]

RL 20:12 S. Rikoslaki 19.12.1889/ 39. Luku 20 Luvattomasta sekaannuksesta ja muusta haureudesta. $12 \mathbb{S}$. [Criminal Act. On Prohibited Intrusion and Other Fornication.] 